\title{
결핵 감시체계
}

대한결핵협회 결핵연구원

\section{권 동 원}

\section{Tuberculosis Suveillance System}

\author{
Dong won Kwon, M.D.
}

The Korean National Tuberculosis Association, Korean Institute of Tuberculosis

\section{서 론}

「감시」라는 뚯을 가지고 있는 서베이란스(Surveillance) 라는 말은 본래 검역용어로서 초기에는 감시대상이 전염병의 접촉자중 발병의 위헙이 있는 사람이었고 (Personal Surveillance) 감시방법도 조직적이지 못하 였다. 그러나 의학 및 역학의 발전과 더불어 감시대상이 질병 (Disease Surveillance) 뿐 아니라 보건사업 전반이 되었고 감시방법도 지속적이고 조직적으로 되었다 ${ }^{1,2)}$.

미국, 영국을 비롯한 여러 선진국에서는 약 350년전 부터 시작·발전되어온 감시체계 (Surveillance System) 를 도입하여 질병관리를 효과적으로 실시하고 있다 ${ }^{3 \sim 6)}$. 1965년 부터는 WHO에서도 하나의 전담부서를 두어 국 제검역질환에 대하여 전세계적인 감시체계를 가동하고 있다 ${ }^{7,8)}$.

감시대상이 질병일 경우 이를 질병감시체계(Disease Surveillance System) 라고 하고 보건사업 전반일 경우 초기에는 이를 공중보건 감시체계(Public Health Suveillance System) 라고 했으나 1986년 미국의 CDC (Centers for Disease Control)에서 이를 역학감시체 계(Epidemiological Surveillance) 라고 부르게 되었 다 ${ }^{9,10)}$.

$\mathrm{CDC}$ 는 “역학감시체계란 보건사업의 계흭 시행 및 평 가를 위하여 반드시 필요한 보건정보 또는 자료를 지속 적으로 수집, 분석 및 해석하여 그 자료를 필요로 하는
정부부서 또는 학계에 때맞추어 제공하는 것을 말한다. 그리고 이러한 노력은 최종적으로 질병의 예방과 관리를 위한 것이며 동시에 보건사업의 발전을 위한 것이다"라 고 정의하고 있담․ 질병감시체계의 정의도 역학감시 체계의 정의와 감시대상이 질병이라는 것 외에는 차이가 없다.

질병감시체계의 일환인 결핵감시체계는 1953년 텐마 크의 결핵 중앙 등록제도(Danish Tuberculosis Index) 가 완성되고 1962년 노르웨이에서 같은 제도가 실시되 므로서 시작되었다고 볼 수 있단) 1968년 선진국의 결 핵문제 해결을 위하여 국제항결핵 및 호홉기 질환 연맹 (IUATLD: International Union against Tuberculosis and Lung Disease)산 하 에 TSRU(Tuberculosis Surveillance Research Unit) 를 설치하고 결핵 문제가 적어진 나라에서의 결핵문제 크기, 측정 및 그 추이를 보는데 적합한 역학적 지표개발, 향후의 결핵환 자발견 방법개선, 그리고 결핵진단 및 치료에 대한 감시 방법의 개발등에 관하여 연구를 하였다. 그러나 결핵 박 멸을 위해서는 선진국 뿐만 아니라 개발도상국에서의 감 시체계도 필요하다는 것이 인정되어 1984년 우리나라와 알제리아의 결핵협회가 이에 가입하게 되었다 ${ }^{12)}$ 따라서 그들로 부터 모든 일을 배우고 또 협력하여 결핵감시의 연구를 진행하여야 하겠다.

영어로는 Tuberculosis Surveillance이지만 우리말 로 번역될 때는 결핵감시. 결핵역학관리정보, 결핵관리 정보조사, 결핵역학관리정보조사, 결핵역학관리정보감 
시, 결핵의 서베이란스 등으로 용어가 통일되어 있지 않 으므로 용어의 통일이 요망된다.

\section{결핵감시의 정의}

결핵감시는 현장의 자료를 지속적으로 수집. 분석하 여 해당집단의 결핵문제의 크기를 밝히고, 결핵관리에 사용되는 대책의 효과를 평가하며, 필요하면 관리대책 의 변경을 권고하는 것으로 정의된다 ${ }^{13)}$. 이 정의에 의하 면 결핵감시체계는 결핵문제의 크기에 대한 감시와 결핵 관리 대책에 대한 감시(programme surveillance)로 구성되어 있고, 효과적이고 효율적인 결핵관리를 실시 하기 위한 결핵관리 대책의 필수적 요소라고 할 수 있 다.

\section{결핵의 자연사(Natural History)와 결핵대책의 역학적 근거}

사람은 결핵균에 감염 안된 상태로 태어 나지만 성장 하면서 지역사회내에 있는 전염원에 노출되어 감염된 다. 감염되면 2 3년 내에 발병하거나 아니면 수년 내지 20 년이상 지난후에 어떤 이유에서든 신체의 방어기능이 약해질 때 발병하게 된다 ${ }^{14)}$. 그러나 만약 특히 어린아이 에 있어서 자연감염이 되기 전에 BCG로 인공감염을 시 키면 발병위험이 감소된다 ${ }^{15)}$. 왜 소수의 감염자중에서
발병이 되는지 아직 정확히 알려져 있지는 않지만 감염 자에게 2 차 화학예방을 실시하면 발병률이 더욱 줄어들 수 있다 ${ }^{16)}$. 그러나 이것은 거의 대부분 비실용적인 조치 이므로 개발도상국에서는 실시하고 있지 않다긱. 결핵 병은 결핵을 의심케하는 엑스선 사진상의 병변단계(결 핵의증)에서 더 이상 진전되지 않고 자연치유될 수 도있 지만 더 진행되어 균양성 환자가 된 다음 자연치유되거 나 사망할 수도 있다. 모든 균양성 환자를 발견하여 치 료하면 지역사회내에 있는 감염위험 률을 감소시켜 결핵 문제의 크기를 직 - 간접적으로 줄일 수 있게 되므로 이 것이 결핵관리 대책의 역학적 근거가 되는 것이다 ${ }^{14}$.

Fig. 1 은 4 개의 역학적 지표-즉 감염위험률, 발병위험 률, 자연치유율, 치명률-를 나타내고 있다.

감염위혐률은 지역사회내에 있는 감염원의 누적된 결 과이고, 발병위험률은 감염자중 발병하는 비율로서 $10 \sim 20 \%$ 로 추정된다. 이들 중 약 $80 \%$ 는 감염후 2 3년 내에 발병하는데 3 년이 경과하면 발병할 위험은 낮으나 감염자의 수가 누적됨으로 이러한 군에서 신환자의 $50 \%$ 이상이 발생한다 ${ }^{14)}$. 발견된 환자의 약절반 가량은 객담 도말 양성환자이다 ${ }^{18)}$.

자연치유율은 균양성 환자중 화학치료없이 자연적으 로 균음전전이 되는 환자의 비율이다.

치명률은 활동성 결핵환자중 치료를 전혀받지 않았거 나 받았어도 해마다 사망하는 환자의 비율이다.

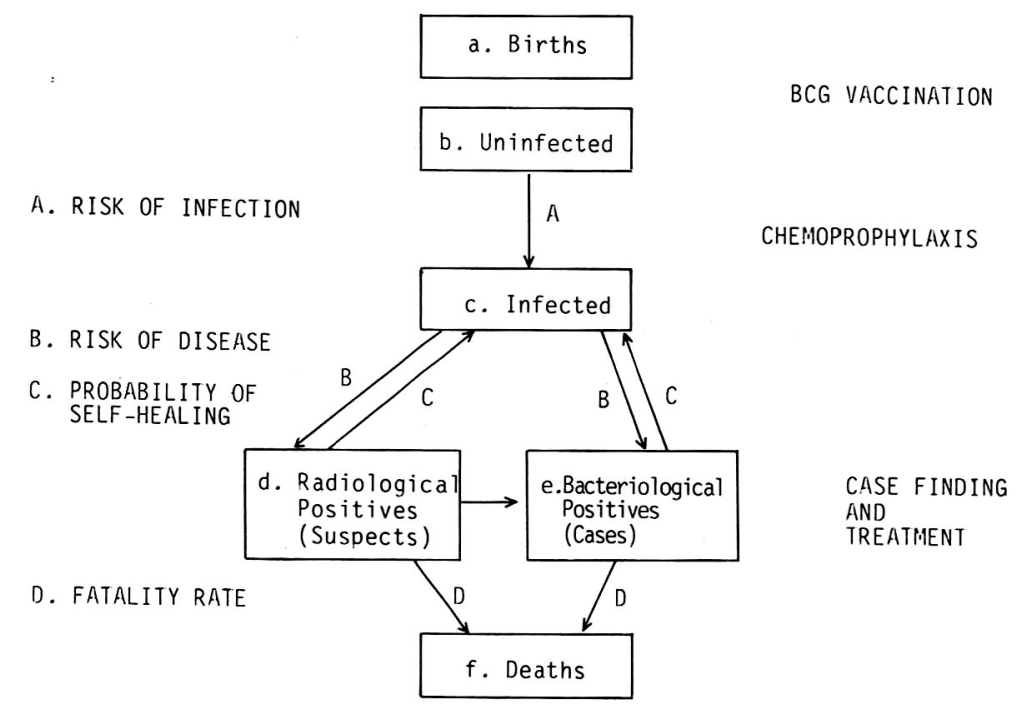

Fig. 1. Diagrammatic representation of the natural history of tuberculosis and the sites of application of specific control measures. 
Table 1. Epidemiological Indices (high prevalence countries)

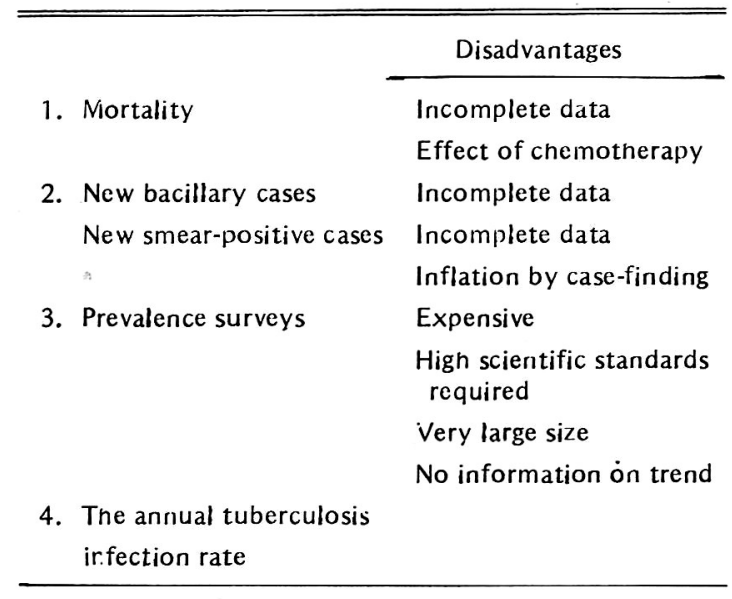

Gryzbowsky에 의하면 치료를 하지 않았을 경우 2 년내 에 약 $40 \%$ 가 사망한다고 한다 ${ }^{19)}$. 5 년내에는 $50 \%$ $\sim 60 \%$ 가 사망한다는 보고도 있다 ${ }^{20 ~ 22)}$.

\section{결핵문제의 크기에 대한 감시}

어느 나라를 막론하고 결핵문제가 순조롭게 감소되고 있는지 아닌지 중단없이 감시하여야 한다. 그러기 위하 여 결핵실태를 잘 반영한다는 역학적 지표들을 사용하지 만 모두 완전한 것이 아니므로 문제의 정확한 파악을 위 하여는 각지표의 장-단점에 대한 이해가 필요하다 (Table 1).

\section{1. 결핵 사망률}

화학요법이 실시되기 전에는 사망통계가 비교적 잘되 어 있고 결핵진단이 비교적 정확했을 것이라고 추정되는 유럽에서 가장 신뢰받던 지표이었다. Styblo 등은 화학 요법이전의 유럽각국의 통계자료로 부터 결핵사망률 : 도말양성 신환 발생률 : 도말양성환자 유병률 $=1: 2: 4$ 라는 관계를 도출하였는데 이런 관계는 유럽각국에서는 비교적 잘 적중되었달). 그러나 화학요법시대가 도래 하면서 Fig. 2에서 보는 바와같이 사망률에 있어서 많은 변화가 있을 뿐 아니라 결핵문제가 중요한 보건문제로 남아있는 나라에서는 사망원인에 대한 자료가 대부분 부 정확함으로 역학적 지표로서의 신뢰성을 상실하게 되었 다. 따라서 결핵사망율을 가지고 결핵문제의 크기에 대

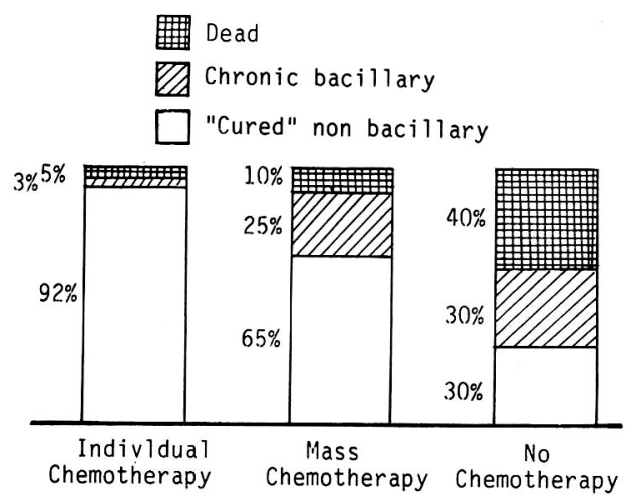

Fig. 2. Percentage of bacillary cases of tuberculosis under different treatment regimens at two years.

한 정확한 연력비교와 국가비교는 할 수 없다고 말할 수 있다 ${ }^{24)}$.

\section{2. 도말양성 신환발생률}

도말양성 환자는 배양양성 환자 보다도 가까운 가족 접 촉자에 대한 감염위험이 5 20배나 더 크므로 이들을 빨 리 발견하여 치료해야 새로운 감염을 효과적으로 막을 수 있다는 것은 이미 잘 알려진 사실이다 ${ }^{25)}$. 도말양성 신환 발생률은 감염원의 크기를 직접 반영하는 기본적인 중요한 지표로서 특히 성별 및 연령별로 나타내면 더욱 효과적이다 ${ }^{26)}$. 그러나 세균검사 기술, 검사회수 및 재료 등의 차이나 환자발견을 위한 노력의 차이등에 의하여 결과가 달라질 수 있는 문제점이 있고 신환발생과 재발 의 구별이 안되는(선진국에서는 거의 구분됨)약점이 있 다 ${ }^{13)}$.

배양양성도 포함된 균양성 신환발생률은 배양기술의 차에 의하여 결과가 달라진다는 이유와 배양양성이 전염 원으로서의 의의가 낮은 이유 때문에 도말양성 신환발생 률 보다 더 나은 의미를 갖는다고 말하기는 어렵다 ${ }^{24)}$.

TSRU가 추천한 양식대로 신환과 재발을 구별하고 성별, 연령별로 구분하여 자료를 얻는 다면 가장 중요한 지표라고 할 수 있다(Fig. 3).

\section{3. 유병률}

우리나라에서 1965년 이후 매5년간격으로 계속 실시 해온 결핵실태조사는 유병률을 알기 위한 가장 정확한 방법이며 이를 통하여 우리나라의 결핵문제의 크기와 그 추이를 파악하여 왔다. 그러나 이 조사는 엄청난 비용, 


\begin{tabular}{l|l}
\hline $\begin{array}{l}\text { Quarterly report on new cases and } \\
\text { relapses of tuberculosis }\end{array}$ & Patients registered during \\
& $\square$ quarter of 1.9 \\
\hline
\end{tabular}

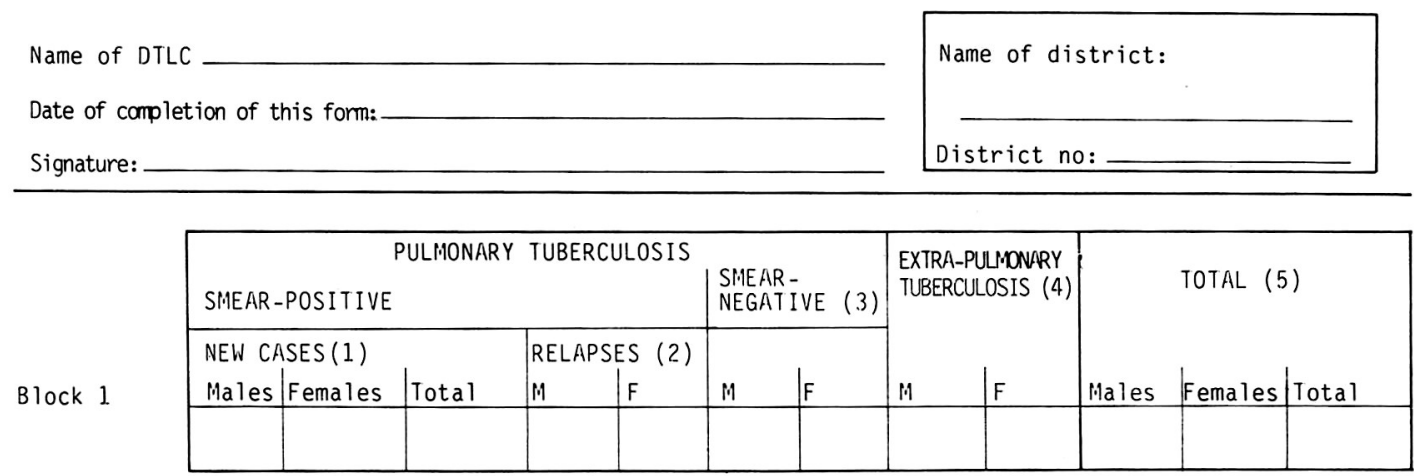

NEW SMEAR-POSITIVE CASES: from Column (1) above

B lock 2

\begin{tabular}{|c|c|c|c|c|c|c|c|c|c|c|c|c|c|c|c|c|}
\hline \multicolumn{2}{|c|}{$\begin{array}{c}\text { Age-group } \\
0-1.4\end{array}$} & \multicolumn{2}{|c|}{$\begin{array}{c}\text { (years) } \\
1.5-24\end{array}$} & \multicolumn{2}{|c|}{$25-34$} & \multicolumn{2}{|c|}{$35-44$} & \multicolumn{2}{|c|}{$45-54$} & \multicolumn{2}{|c|}{$55-64$} & \multicolumn{2}{|c|}{65 or more } & \multicolumn{3}{|c|}{ TOTAL } \\
\hline$M$ & $\mathrm{~F}$ & $M$ & $\mathrm{~F}$ & $M$ & $\mathrm{~F}$ & $M$ & $\mathrm{~F}$ & $M$ & $\mathrm{~F}$ & M & $\mathrm{F}$ & $M$ & $\mathrm{~F}$ & Males & Females & Total \\
\hline & & & & & & & & & & & & & & & & \\
\hline
\end{tabular}

Fig. 3. Format for reporting new cases and relapses of tuberculosis.

인력 및 시간이 소요되며, 유병률이 낮아질수록 조사 대 상자의 규모가 더 커져서 이들의 협조를 구하기 힘들며, 진단기준이 조금만 변해도 결과에 큰 영향을 받고, 치료 실패자가 많이 누적되면 그것에 의하여 영향을 받는 등 많은 문제점이 있다. 우리나라에서는 이제 더 이상 실태 조사를 할 수 없게 되므로 다른 방법을 통하여 유병률과 신환발생률을 파악하지 않으면 안된다.

연말의 정기보고서에 의해서도 유병률을 알 수 있으나 이 경우 진단기준의 차이. 신고이행 여부 및 과잉치료 유무 등에 의하여 많은 영향을 받으므로 아주 신뢰할 수 있는 지표는 못된다.

\section{4. 감염 위험률}

감염위험률이란 결핵균에 감염안된 사람이 1 년동안에 결핵균에 감염되는 율로서 이는 결핵균의 감염전파의 사 슬을 끓으려는 결핵관리 대책의 목적을 직접 측정할 수
있다는 장점을 가지고 있다. 그러나 이외에도 투베르쿨 린 검사는 방법이 간단하고 용이하며, 결과가 객관적이 고 재현성이 풍부하고, 신환발생률과 같이 진단의 기준 이나 대책의 강도에 영향을 받지 않으므로 결핵문제 크 기의 연력 비교나 국제비교에 적합하다 ${ }^{24)}$. 또한 감염위 험률과 그 연간 감소율을 알 수 있기 때문에 연간 감소율 이 미래에도 불변한다고 가정하면 결핵감염의 미래추정 이 가능해 진다. 뿐만 아니라 결핵감염의 발생률과 유병 률 및 결핵 신환발생률도 예측이 가능하다 ${ }^{26 ~ 31)}$. 이러한 장점들 때문에 가장 신뢰할 수 있는 지표로 세계에 널리 인정되었고 이를 이용한 역학 연구가 급속히 발전되고 있다. 그러나 투베르쿨린 검사로는 비결핵 항상균이나 $\mathrm{BCG}$ 에 의한 감염을 구별할 수 없으므로 전자에 의한 감 염이 많거나 후자의 접종률이 높은 나라에서는 문제가 있다. 따라서 그러한 곳에서는 그 나라를 대표할 수 있 는 지역을 무작위로 선정하여 그곳에 있는 아동들에게는 
Table 2. The Annual Tuberculosis Infection Rate (risk of infection)

\begin{tabular}{l} 
Problems of assessment \\
\hline - Infection with "atypical" mycobacteria \\
- Mass BCG vaccination at birth \\
Advantages \\
- A simple measure of the impact of tuberculosis \\
On the community at different times \\
- Internationally comparable \\
- Predictions : incidence of TB infection \\
prevalence of TB infection \\
incidence of TB disease
\end{tabular}

BCG접종을 주지 않고 그들을 대상으로 매년 투베르쿨 린 검사를 반복할 수 있다 ${ }^{23)}$. 또 다른 대안으로는 정기 적인 등록제도를 통하여 얻어지는 신환발생률로서 결핵 실태를 추정하거나 간접적인 방법으로서 0-4세 어린아 이의 결핵성 뇌막염 발생률이나 20 29세 성인에서의 균양성 신환발생률로 부터 감염위험률을 추정하는 것이 다 ${ }^{13)}$ (Table 2).

더 신뢰할 수 있는 역학적 지표의 개발이 요구된다.

\section{결핵관리 대책에 대한 감시}

결핵문제의 크기는 지역사회내의 개개의 결핵대책의 총화와 역학적인 상황에의하여 결정된다. 결핵문제를 개선시키기 위하여 보건정책 입안자는 어디에 문제가 존 재하는지 인식해야만 한다. 결핵감시는 지역사회의 결 핵문제를 평가하는 것과 관계가 있으므로 개개의 결핵대 책에 대한 감시는 기존하는 감소추세와 더불어 결핵대책 에 의하여 야기되는 결핵실태의 변화를 나타내야만 한 다.

결핵관리 대책의 감시를 위해서는 개개의 대책의 목적 을 분명히 이해하고 있어야 한다. 그 목적은 주어진 상 수(parameter)의 값을 변화시킴으로 결핵의 자연사를 방해하는 것이다.

$\mathrm{BCG}$ 접종의 목적은 최근에 감염된 사람 중에서 결핵 의 발병을 감소시키는 것이다. 즉 최근 감염자와 활동성 결핵환자 사이의 상수를 낮추려는 것이다.

진단 및 치료의 목적은 전염원의 평균 감염기간을 단 축시키고 지역사회내에 있는 감염원의 수와 감염되는 사
람수 사이의 수적관계를 나타내는 상수를 감소시키는 것 이다. 전염기간은 두 시기로 나누어 지는데 첫 시기는 치료개시전의 전염성기로서 이 기간을 단축시키는 것이 환자발견대책의 목적이고 두번째 시기는 치료개시후의 전염성기로서 이기간을 단축시키는 것이 치료의 목적이 다 ${ }^{13)}$.

개개의 대책으로 상수 값을 개선 시키면 그 결과로 전 체 결핵문제의 개선이 있게된다. 보건정책 입안자는 대 책의 장 - 단기적 효과를 잘 알아야 한다. 역학적 모델을 사용하면 상수 값을 변화 시킴으로서 이 목적을 달성할 수 있다.

\section{BCG 접종 사업 감시}

상술한 BCG접종사업의 목적을 달성하기 위해서는 $\mathrm{BCG}$ 왁친의 품질관리, 접종률, 접종의 기술적 평가, 접 종의 효과, 접종후 발생하는 부작용의 형태와 빈도 및 집단접종의 중단시기 등에 대한 자료 수집이 있어야 한 다.

\section{2. 환자발견 및 치료사업 감시}

환자발견 및 치료사업의 목적은 감염원의 감염기간을 감소시킴으로 결핵균의 전파를 방지하는 것이다. 환자 발견 그자체는 감염을 감소시키는 것이 아니므로 발견 및 치료대책을 따로 떼에서 생각할 수 없다 ${ }^{25)}$.

환자발견 및 치료사업 감시를 위해서는 다음과 같은 문제에 대한 해답이 있어야 한다.

1) 지역사회내에 존재하는 총감염원중 일년동안에 얼 마나 발견되는가? 이문제는 매우 어렵지만 반드시 해결 해야 한다. 발견되는 감염원의 수는 알 수 있지만 존재 하는 감염원의 총수는 알 수 없으므로 가정이 반드시 필 요하다. 예를들면, 한 감염원이 일년동안 5 명에게 감염 을 일으키고, 성인의 감염위험률이 아동의 그것과 동일 하다고 가정하면, 일년동안에 감염된 사람의 수를 가지 고 존재하는 모든 전염원의 수를 계산할 수 있다 ${ }^{13)}$.

2) 환자로 하여금 의료기관을 방문하게 한 주 증세는 무엇인가 ? 처음 방문한 의료기관의 종류와 만약 가능하 다면 검사종목과 치료처방을 아는 것도 중요하다.

3) 증세의 출현후 얼마나 빨리 의료기관을 찾았는가 ? 기침이 나면서 부터 환자가 균을 배출한다고 하면, 그때 부터 주위사람들에게 감염을 일으켰다고 의심 할 수 있 다. 이 감염기간을 환자 수진지연 (patient's delay)이라 


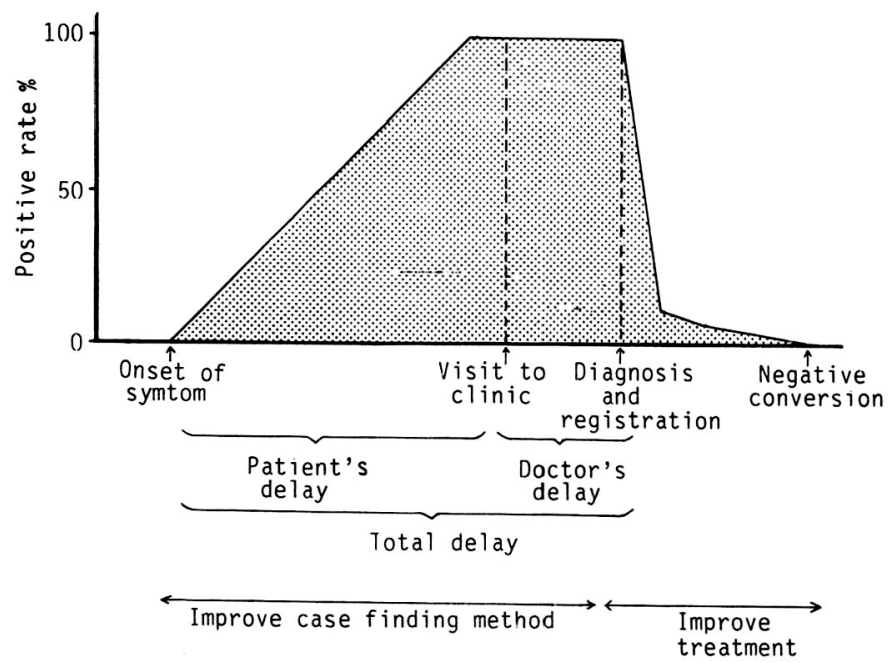

Fig. 4. Patient's delay and Doctor's delay

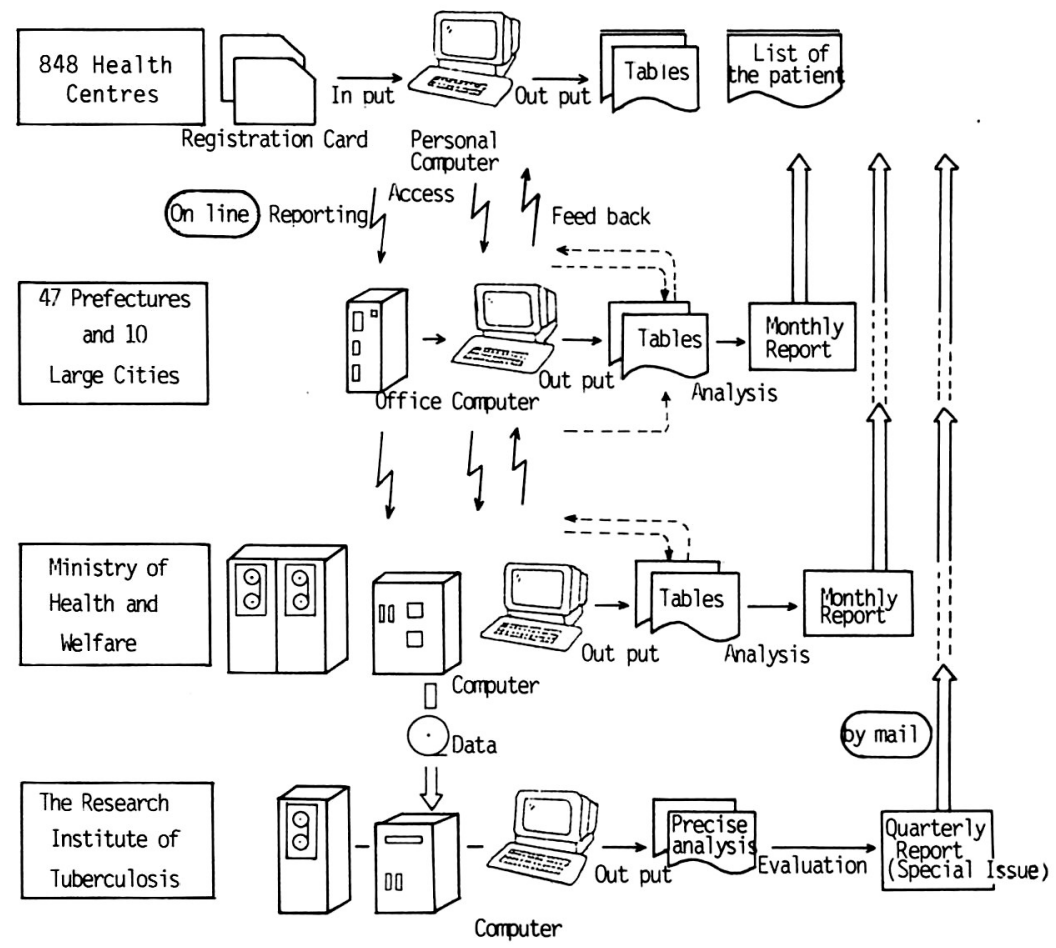

Fig. 5. Tuberculosis Surveillance System in Japan

고 한다(Fig. 4).

4) 첫 의료기관 방문후 얼마나 일찍 결핵이 발견되었 는가 ? 화학치료를 시작할때 까지 환자는 전염력이 있 으므로 이 감염기간을 의사진단지연 (doctor's delay)이 라고 한다 ${ }^{13)}$.
환자 수진지연과 의사진단지연을 합한것을 총지연 (total delay)이라고 하는데 이 기간이 환자가 감염을 일으키는 전체기간이며, 이를 통하여 환자발견이 늦은 주 원인을 발견할 수 있다(Fig. 4).

5) 전체발견 환자중 균양성 환자의 비율은 얼마인 
가 ?

6) 치료가 시작된 환자중 균음전율, 조기퇴록률 및 중 단퇴록률은 얼마이고 그 원인은 무엇인가 ? 치로실패 율, 치료효과 및 효율은 얼마인가 ? 이러한 것은 코호트 분석방법(Cohort analysis) 으로 알수 있다.

7) 이외에도 치료후의 재발률, 초회내상의 빈도, 치료 기간, 입원기간, 과잉치료율 등은 얼마인가 ?

\section{외국의 결핵감시 체계}

외국의 예로 일본을 든다: 일본은 이체계를 1975년 에 오끼나와현에 처음 도입하여 결핵관리의 획기적인 진 전을 가져오자 컴퓨터를 이용한 유사한 감시체계를 아이 찌현과 시주오까현에 1980년과 1985년에 각각 설립하였 다.

후생성의 결핵 자문 위원회에서는 유병률이 높던 국가 의 결핵관리 체제에서 낮은 국가의 체제로 전환하고, 재
래의 전통적 방식에서 현대적인 방식으로 전환하기 위해 서는 전국적인 규모의 결핵 감시체계의 확립이 필요하다 고 역설하였다. 1987년에 일본정부는 마침내 킴퓨텨를 이용한 결핵 및 전염성 질환감시체계를 확립하기로 결정 하였다.

이 감시체계에는 대규모의 3 단계 자료처리 씨스템이

Table 3. Programme Prepared for H.C.

\begin{tabular}{l}
\hline 43 programmes \\
\hline 1. List of the patients registered for 5 years or more \\
2. No. of newly registered by sex, age, X-ray findings \\
and bacteriology \\
3. No. of newly registered, chemotherapy regimen, \\
X-ray findings, bacteriology and relapsed/not relaps- \\
ed \\
4. Distribution of delay by X-ray findings \\
5. Distribution of the duration of registration and bac- \\
teriology by the first X-ray findings and bacteriology
\end{tabular}

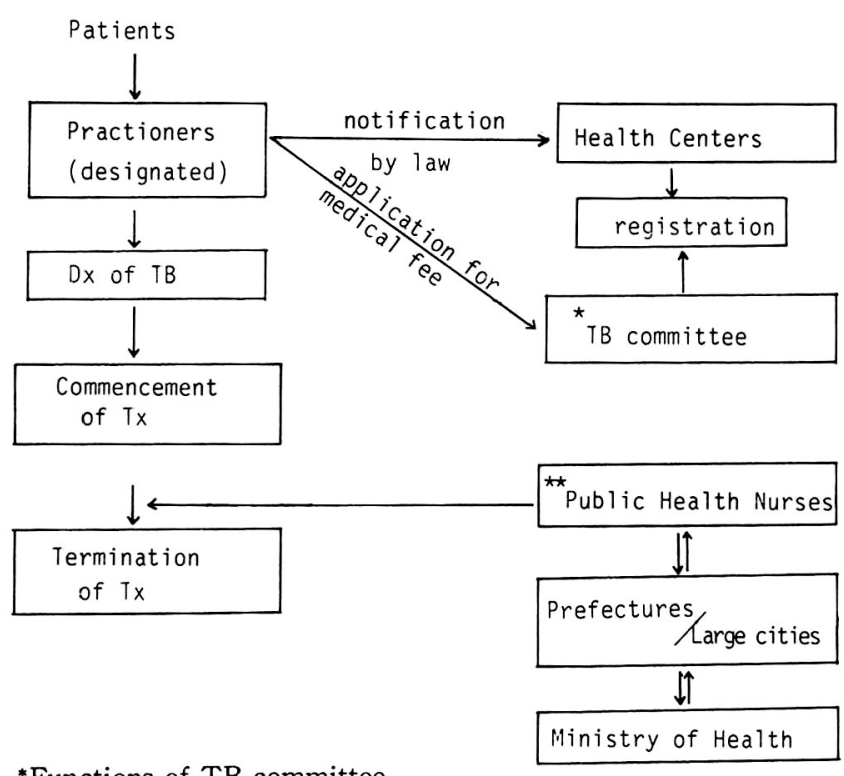

*Functions of TB committee

1. Establishment of diagnosis

2. Decision of regimen

3. Rogulation of treatment duration

**Functions of public health nurses

1. Registration of TB patients

2. Health educaton to registered patients

3. Case-holding until cure

Fig. 6. Relationship between the National Tuberculosis Control Programme (case-finding, treatment and case-holding) and the Medical Insurance System in Japan 
848 개의 보건소, 57 개의 현/대도시, 및 후생성에 연결되 어 있다(Fig. 5). 수집된 정보의 분석을 위해서 보건소 단위에서는 43 개의 프로그램에 의하여 5 년이상 등록중 인 환자 및 등록후 1 년이 경과한 자로서 도말양성자 등 의 리스트를 작성할 수 있다 (Table 3).

환자수진지연, 의사진단지연 및 총지연, 치료기간의 분석등도 유용한 프로그램에 의하여 수행된다.

현단위에서는 50 개의 프로그램을 이용하여 수집된 정 보를 보다 면밀히 분석한 후 그 분석결과를 해당 현에 있 는 보건소별로 비교하고 문제점이 있는 보건소에는 즉시 연락하여 문제점을 즉시 시정하도록 한다.

국가단위에서는 자료의 정밀분석이 결핵연구원에서 행 해지고 있다. 결핵전문가들로 구성된 국가결핵감시 위 원회는 필요할 땐 언제든지 소집된달)

이러한 조직적인 체계는 개업의의 완벽한 신고체재와 그의 이행에 기초를 두고 그위에 결핵전문가 및 지역의 사회회원등 5 인으로 구성된 보건소 결핵 자문위원회의 역할-죽 신고된 환자에 대한 결핵진단 및 처방의 정확성 여부를 핀단후 보건소에 환자를 등록시키고 등록이 되어 야만 치료한 환자에 대한 의료비를 개업의가 청구할 수 있도록 함-과 등록된 환자가 개업의 한테 완치될때 까 지 성실히 치료받을 수 있도록 가정방문 및 보건교육을 실시하는 공중보건 간호사의 역할등에 바탕을 두고서 이 루어지고 있다(Fig. 6).

\section{맺음 말}

Canetti에 의하면 결핵박멸이란 문자그대로 현존하는 환자를 모두 완치시키고 새로운 환자가 더 이상 출현하 지 않는 상태를 의미한다고 하였다 ${ }^{33)}$. 그러나 이러한 의 미의 결핵박멸이란 예측할 수 있는 미래에 달성될 수 없 으므로 Styblo는 결핵박멸에 대하여 두개의 실용적인 정의를 내리고 있다. 하나는 결핵박멸에 가까운 상태로 서 도말양성 신환 발생률이 인구 100 만명당 1 명 미만이 거나, 결핵 감염유병률이 전체인구의 $1 \%$ 미만으로서 계 속 감소하는 상태이다. 또 다른 하나는 실제로 결핵이 박멸된 것과 마찬가지인 상태로서 도말양성 신환 발생률 이 인구 1000 만명당 1 명 미만이거나 결핵감염 유병률이 전체인구의 $0.1 \%$ 미만으로서 계속 감소하는 상태이 다 ${ }^{34,35)}$. 노르웨이, 텐마크, 미국등에서는 2010년에 전 자의 상태에 도달하겠다는 목표를 세우고 힘차게 전지하
고 있지만 ${ }^{36}$ 우리나라의 경우에는 결핵문제의 감소속도 가 현상태로 지속된다면 향후 100 년 이상 걸릴런지 모른 다. 따라서 보다 신속히 결핵문제를 줄이기 위해서는 물 론 혁신적인 새로운 진단, 치료, 예방기술 개발 및 그 이 용도 중요하겠지만 기존해 있는 결핵관리 대책을 보다 효과적으로 사용하는 것이 더욱 중요할 것이다. 그러한 목적의 달성을 위해서 절대적으로 필요한 것이 결핵 감 시체계의 도입이다 ${ }^{36)}$. 다행히도 우리나라는 지난 수십 년간의 눈부신 사회 경제적 발전에 힘입어 1989년 7 월 1 일 부터 전국민 의료보험이 실시되고 그 업무가 전산화 되어있다. 이의 실시 이후 보건소 결핵 환자수의 감소 추세가 현저히 나타나고 있는 반면, 일반 병 - 의원 이용 이 증가할 것으로 예상되는 바 전 국민 의료보험 전산망 을 이용한 감시체계 수립이 더욱 절실한 실정이다.

이 체계가 수립되면 우리나라의 결핵관리사업이 안고 있는 많은 문제점 즉 국가 결핵관리체계가 이원화 되어 있어 격핵환자가 보건소와 민간 병 - 의원에서 서로 다른 원칙하에서 관리되고 있는 문제, 민간 병 - 의원의 결핵 환자신고 불이행으로 인한 환자들에 대한 정보 부족으로 5 년에 한번씩 막대한 비용과 노력이 소요되는 실태조사 를 해야만 하는 문제, 실태조사를 통해서는 유병률은 알 수 있지만 중요한 역학적 지표인 균양성 신환 발생률 은 알 수 없는 문제등을 해결할 수 있게 될 것이다. 그러 나 의료보험 전산망을 이용한 결핵감시체계 수립시 반드 시 고려해야만 할 사항은 진단의 정확성, 처방의 정확 성, 치료기간의 정확성 및 환자관리의 정확성 보장이다. 왜냐하면 진단이 정확지 못하면 결핵정보가 정확할 수 없고, 처방이 정확지 못하면 치료가 성공할 수 없고, 치 료기간이 정확지 못하면 보험재정이 낭비되고, 환자관 리가 정확지 못하면 난치성 환자를 만들 수 있기 때문이 다. 또한 이 모든것이 다 결핵문제의 크기 및 의료보험 재정과 밀접한 관계가 있기 때문이다. 따라서 이 4 가지 가 보장될 수 있는 제도적 장치가 마련되어야 하며 이를 위한 연구위원회가 각계 전문가들로 구성되어야 할것으 로 생각된다.

우리도 시대적 요구에 부응하는 합리적이고 과학적인 결핵감시체계를 수립하여 결핵박멸의 날을 하루라도 앞 당기도록 우리 노두가 다 노력하여야 하겠다. 


\section{REFERENCES}

1) World Health Organization: Report of the technical discussions at the twenty-first World Health Assembly on "National and Global Surveillance of Communicable Diseases." A21/Technical Discussions/5. Geneva: WHO, May, 1968

2) Langmuir $\mathrm{AD}$ : The surveillance of communicable diseases of national importance. N Engl J Med 268: 182-192, 1963

3) Langmuir AD: Evolution of the concept of surveillance in the United States. Proc R Soc Med 64:681 $-689,1971$

4) Hartgerink MJ: Health surveillance and planning of health care in the Netherlands. Int J Epidemiol 5:87 $-91,1976$

5) Anonymous(Editorial): Surveillance. Int $J$ Epidemiol 5:3-6, 1976

6) Centers or Disease Control: Manual of procedures for national morbidity reporting and public health surveillance activities. Atlanta, GA: CDC, 1985

7) Raska K: National and international surveillance of communicable diseases. WHO Chronicle 20:315, 1966

8) Lucas AO and Langmuir AD: The surveillance of comnunicable diseases. WHO Chronicle 22:439, 1968

9) Stephen B. Thacker and Ruth L.Berkelman: Public Health surveillance in the United States. Epidemiological Reviews 10:164-185, 1988

10) Carper P.: The epidemiological surveillance of medical care. Am J Public Health 77:668-669, 1987

11) Cnnters for Disease Control: Comprehensive plan for epidemiologic surveillance: Centers for Disease Control. August 1986, Atlanta, GA: CDC, 1986

12) 보건사회부. 대한결핵협회 : 결핵관리. 1989

13) The Research Institute of Tuberculosis, Japan Antituberculosis Association: Tuberculosis Control. WHO/Japan International Tuberculosis Course. Japan, 1985

14) Pan American Health Organization: Tuberculosis Control: A manual on methods and procedures for integrated programs. Pan American Health Organization, Washington. DC, 1986

15) Shashidhara AN: An introduction to tuberculin testing and BCG vaccination. IBH PRAKASHANA, Bangalore, 1980
16) Grosset J: Present and new drug regimens in chemotherapy and chemoprophylaxis of tuberculosis. Bull Int Un Tuberc Respir Dis 65(2-3) : 86-91, 1990

17) World Health Organization: WHO Expert Commit. tee on Tuberculosis:Ninth report. Geneva, World Health Organization, 1974

18) Murray CJL, Styblo K and Rouillon A: Tuberculosis in developing countries: burden, intervention and cost. Bull Int Un Tuberc Respir Dis 65 (1) :6-24, 1989

19) Gryzybowsky: Epidemiology of tubercuolsis and the role of BCG. Clinics in Chest Medicine 1 (2):175-187, 1980

20) Drolet GJ: Present trend of case fatality rates in tuberculosis. Am Rev Tuberc 37;125-151, 1938

21) Lindhart $M$ : The statistics of pulmonary tuberculosis in Denmark, 1925-1934, A statistical investigation on the occurrence of pulmonary tuberculosis in the period 1925-1934, worked out on the basis of the Danish National Health Service profile of notified cases and of deaths. Copenhagen, 1939

22) Galtung Hansen O:Tuberculosis mortality and morbidity and tuberculin sensitivity in Norway. Copenhagen: WHO Euro-84/15, 1955

23) Styblo K: Epidemiology of tuberculosis. In:Meissner $\mathrm{G}$ and other editors. Infektionskrankheiten und ihre Erreger. Mykobacteria und mykobakteriellen Krankheiten 4:82-86, 1984

24) Styblo K: Epidemiological indices for planning, surveillance and evaluation of tuberculosis programmes. Bull Int Un Tuberc, 49:66-75, 1974

25) Toman K: Tuberculosis case findings and chemoth. erapy. Questions and answers. World Health Organization, Geneva, 1979

26) Styblo K, Meijer J, Sutherland I: The transmission of tubercle bacilli, its trend in a human population, Tuberculosis Surveillance Research Unit, Report No 1. Bull Int Un Tuberc 42:5-104, 1969

27) Styblo K: Recent advances in epidemiological research in tuberculosis. Adv Tuber Res 20:1-63, 1980

28) Styblo K: The relationship between the risk of tuberculosis infection and the risk of developing infectious tuberculosis. Bull Int Un Tuber 60(3-4): 117-119, 1985

29) Styblo K: Tuberculosis control and surveillance. In: Flenley DC and Petty TL. Recent Advances in Respiratory Medicine 4:77-108, 1986

30) Southerland I: Recent studies in the epidemiology of 
tuberculosis. based on the risk of being infected with tubercle bacilli. Adv Tuber Res 19:1-63, 1976

31) World Health Organization: Tuberculosis control as an integral part of primary health care. World Health Organization, Geneva, 1988

32) Aoki M: Tuberculosis surveillance system in Japan. Bull Int Un Tuber Respir Dis 65(2-3):44-47, 1990

33) Canetti G: L'eradication de la tuberculose dans les différents pays, compte tenu des conditions existantes (problems théoriques et solutions pratiques). Bulletin de L'union Internationale contre la Tuber- culose 2:605-642, 1962

34) Styblo K: Eradication of tuberculosis in developed countries in the HIV era. Bull Int Un Tuberc Respir Dis 64(3):58-64, 1989

35) Styblo K: The elimination of tuberculosis in the Netherlands. Bull Int Un Tuberc Respir Dis 65(2-3): 49-55, 1990

36) Centers for Disease Control: Morbidity and Mortality Weekly Report (supplement), April 121, Altanta, GA: CDC, 1989 